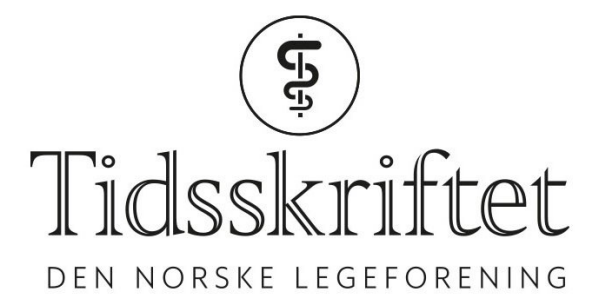

\title{
Trenger ting å ta så lang tid?
}

INTERVJU

CHRISTINA SVANSTR ØM

E-post: christina@svanstrom.no

Professor Arthur Revhaug (70) tenker koronapandemien skaper rom for nødvendige endringer i helsevesenet.

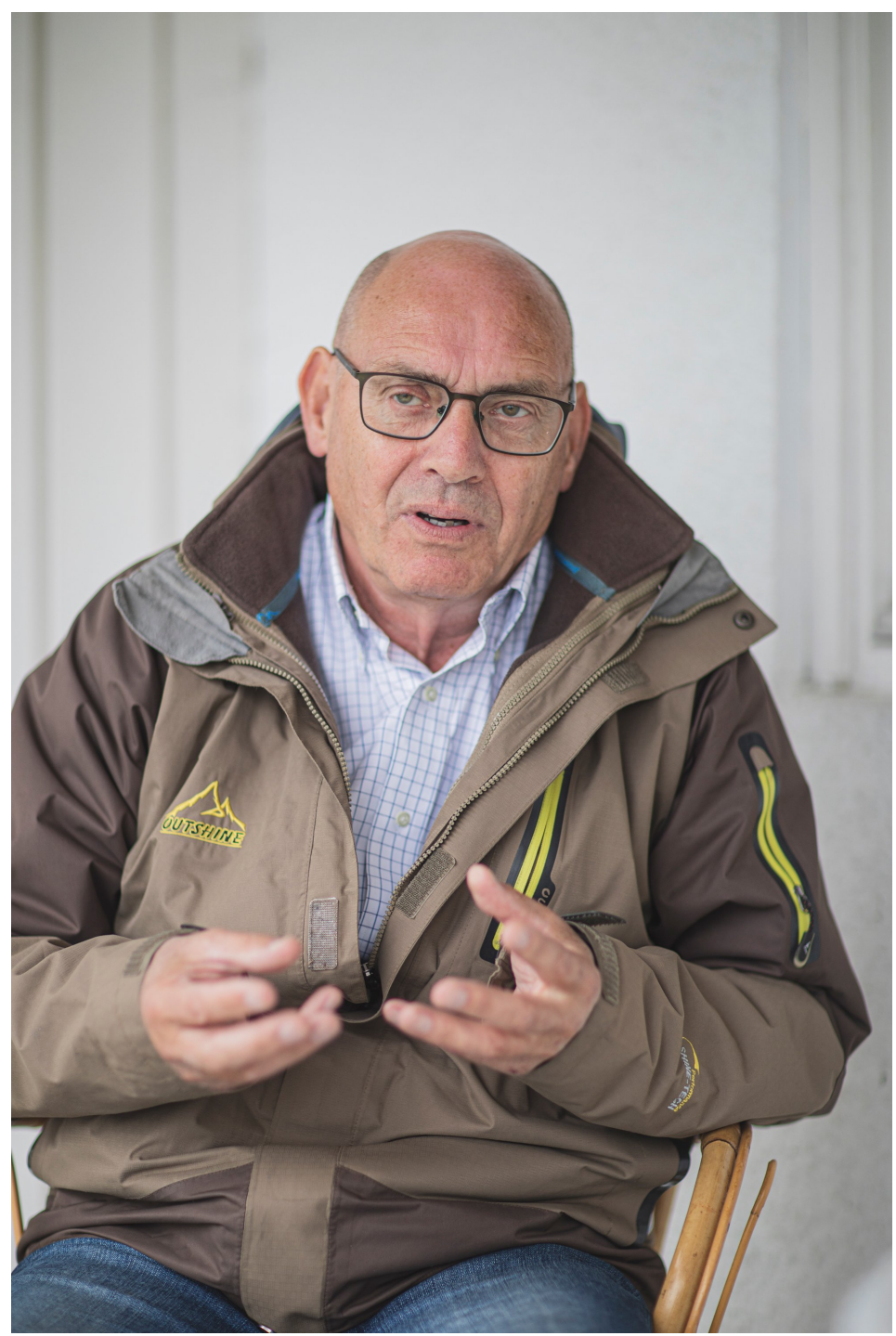

Foto: Marius Fiskum

Vi har snakket oss gjennom en blomsterhage, rundt alle husets fire hjørner og over en kopp 
kaffe utenfor hans bolig på Tomasjord i Tromsø. Ikke innendørs, men ute. Og alltid minst én meter fra hverandre. Eller mer korrekt, seks fot, som professor Revhaug presiserer. Vi lever i koronaens tid, og da tar ikke intervjuet noen lemfeldig form.

- Ja, det har blitt mye tid i hagen i år?

- Absolutt. Gjennom våren er det her jeg har brukt mest tid, sier Arthur, og forsvinner inn ytterdøra.

Ut kommer han med fire små sitronplanter i en felles liten potte, som får plass på

kaffebordet sammen med oss. Det begynte med seks sitronfrø i slutten av mars.

- Jeg tok av det hardeste skallet og la det en ukes tid på et vått tørkepapir. Deretter begynte det å spire. Slik sparer man en måneds spiretid.

- Er det håp om å få sitroner?

- Ja, men da må vi holde ut noen år. Jeg har ivret for at vi skal skille dem. Men Astrid sier at de liker seg i en skog. Enn så lenge står de sammen.

Hjemme fra vinterhagen ble det ikke bare holdt oversikt på vårens vekster. Med sitt internasjonale fellesskap av kollegaer og venner opplevde Arthur Revhaug at han tidlig fikk innsikt i utviklinga av koronapandemien.

- Flere land i Asia har klart å holde seg til en helt annen løsning enn det kollapset vi har i vestlige land. Det er uforståelig for meg hvor langsomt vi lyttet til det de allerede hadde lært i Asia. Å late som om deres kunnskap om situasjonen ikke skulle ha konsekvenser for oss, forstod jeg ikke. Derfor ble jeg veldig glad da våre myndigheter agerte. Norge kunne lett ha kommet i samme situasjon som i en del europeiske land og USA.

- Er det snakk om en vestlig arroganse?

- En vitenskapelig, kulturell og politisk arroganse. Lederen i Verdens helseorganisasjon (WHO) ba lenge og innstendig om at vi skulle teste, spore og agere. Men det tok for lang tid. Og her sitter vi.

\section{Risikogruppa}

De fire sitronplantene som klarte seg gjennom våren, har nå fulgt Arthur i hele den selvpåførte karantenetiden. Hans ryddige måte å forholde seg til den nye normalen eksemplifiserer holdninga han har holdt gjennom en årrekke som kirurg og leder. Det faglige og det menneskelige står i første rekke.

\section{Arthur Revhaug}

Født 1950

Gift med Astrid Elisabeth, 4 barn, 10 barnebarn og 1 oldebarn

Cand.med., Universitetet i Santiago de Compostela 1975

Dr.med., Universitetet i Troms $\emptyset 1985$

Research Fellow i kirurgi, Harvard Medical School 1985-86

Professor i kirurgi, Universitetet i Tromsø 1988

Seksjons/avdelingsoverlege, Gastrokirurgisk avdeling, Universitetssykehuset Nord-Norge

1988-2008

Gjesteprofessorat i Barcelona 1995-96 og i Montpellier/Paris 2001-02

Klinikksjef, Kirurgi, kreft og kvinnehelseklinikken, Universitetssykehuset Nord-Norge 2008-18

- Hva tenker du om å være definert i en risikogruppe?

- Det er en uvant kategori, men den må erkjennes. Det er ingen grunn til å late som om jeg 
er yngre enn jeg er når jeg har både medisinske og aldersmessige risikofaktorer. Jeg er ikke stup dum heller.

Kategoriene er som de er. For Revhaug er det viktigere å fokusere på at koronaen utfordrer etablerte sannheter i det medisinske miljøet:

- Den randomiserte kontrollerte studien er gullstandard. Skulle vi ha brukt den metoden nå, ville det tatt år før vi hadde svar. Jeg tror at vi ved å jobbe annerledes - raskere - kan få store nok mengder data til å samle systematisk kunnskap like trygt som i de randomiserte kontrollerte studiene.

Å legge planer er en ting, å skape varig endring er noe annet. Ting Tar Tid. Likevel, gjennom våren 2020 poppet det fram IT-løsninger som kunne ta land og helse videre når all fysisk kontakt ble utsatt.

- På kort tid la vi om drifta. Poliklinisk arbeid ble gjort på video eller telefon. En slik endring har vi forsøkt å få til i 15 år - men nå bare skjedde det. Jeg tror vi sitter igjen med mange varige endringer.

Selv kan han fra stua hjemme på Tomasjord holde et øye med pulsen via smartklokke. Opplever han uregelmessig rytme, sender han en EKG-utskrift over til sykehuset på minutter.

- Kardiologen kan tyde denne utskriften like bra som ved en Holter-monitorering- og det fra en situasjon med pågående symptomer. Poenget er at de teknologiske løsningene er her og utvikles i eksponentiell hastighet. Vi må sørge for at vi tar i bruk de smarte tingene.

\section{Pasientens beste}

Teknologien gir oss muligheter til å løse samtidskonflikter i tid og rom. Det er viktig for Revhaug å understreke at de løsningene vi velger framover, må ta oss mot et felles mål om pasientens beste.

- Doktorene sklir unna pasientene. Vi har bygd et system der den menneskelige relasjonen mellom pasient og behandler er vanskelig å ivareta. Det er veldig mange fine folk som gjør jobben sin, men de strever med at det ikke er kontinuitet. Klarer vi å knekke koden, vil pasientene sitte igjen med en bedre opplevelse. 


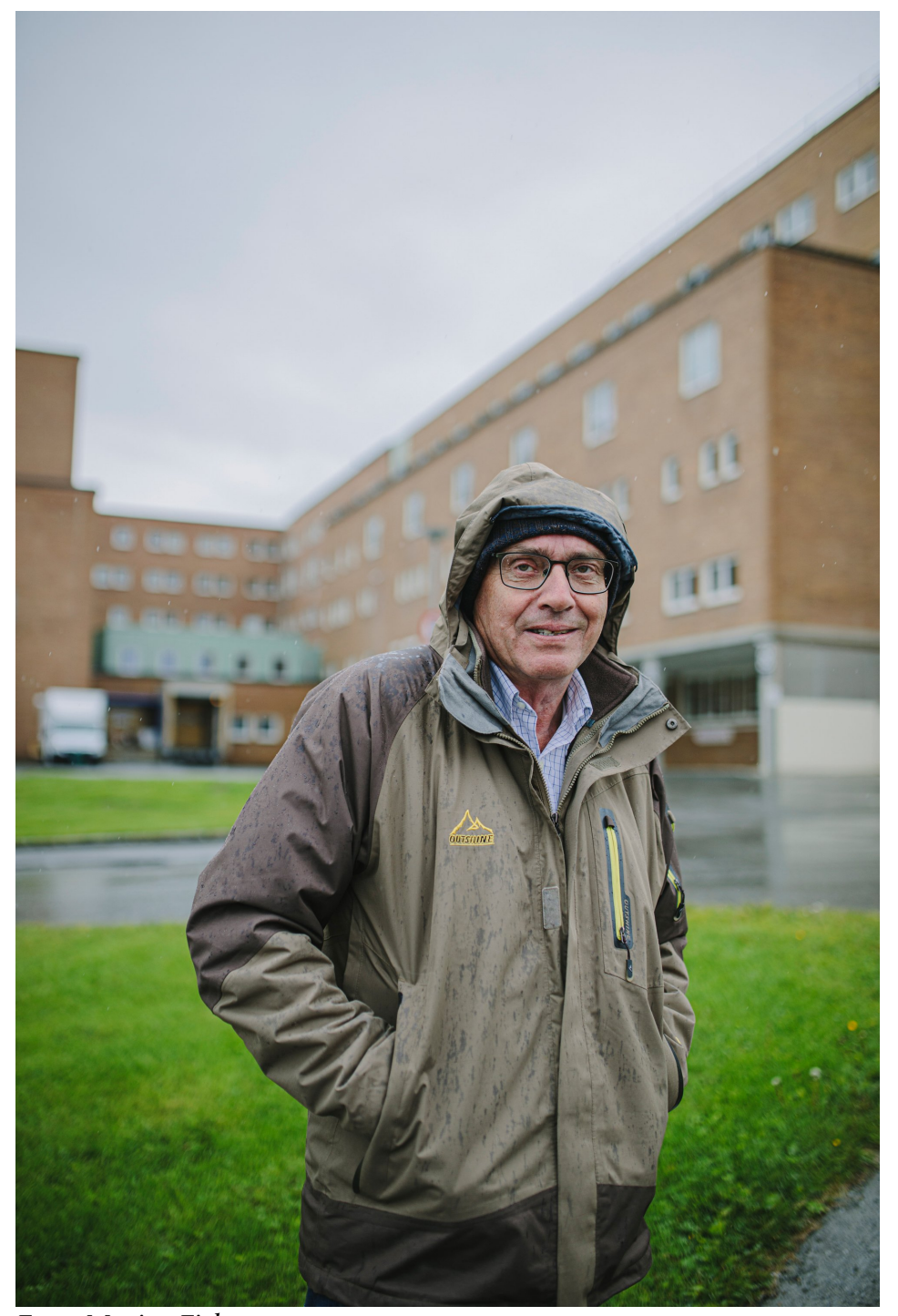

Foto: Marius Fiskum

- Er det egentlig rom for denne kontakten i dag?

- Nei, det er ikke det. Derfor må helsevesenet endres, ikke pasientene. Hvem er sykehuset til for - oss som jobber der, eller pasienten?

Den randomiserte kontrollerte studien er gullstandard. Skulle vi ha brukt den metoden nå, ville det tatt år før vi hadde svar

- «Pasientens helsevesen» er et ideal mange kan stille seg bak. Men mens vi vokser inn i nye teknologiske løsninger, hvordan skal vi ivareta det mellommenneskelige?

- Jeg har selvsagt ikke svar på det. Men jeg mener at dette er spørsmål vi må stille oss, og at vi må aktivt frigjøre oss fra unødige oppgaver. Vi må se hva pasientene trenger, og sørge for at de får det. Det er motivasjonen for å være doktor, i hvert fall for meg.

For å få til det gode helsearbeidet mener han det handler om å kombinere fag og miljø. Vi må skape arbeidsplasser på tvers av fagprofesjonene som er gode for pasienter og ansatte.

- Du skal ha sagt «heller for få folk enn folk som drar i feil retning»?

- Ja. Det verste er folk som drar i feil retning. Det er livsfarlig.

- Hvordan finner man så de riktige folka?

- Vi må stille krav. Aktive og engasjerte mennesker har glede av forventninger som det er mulig å innfri. Det handler om å tørre å sette et felles mål og si hvor vi skal. Det gir friksjon, men det er kanskje det som må til? Det viktige er at vi har samme retning.

- Og det er? 


\section{Pilgrim fra Pers Hotell}

Arthur og kona Astrid møttes da de var 16 år gamle. Egentlig hadde gårdsbarnet Arthur fra Råde planer om å bli dyrlege. Men da han og Astrid var ferdig på videregående skole, ville en biltur det annerledes. Under en stopp på Pers Hotell i Hallingdal kom Arthur over en Dagsrevyen-sending.

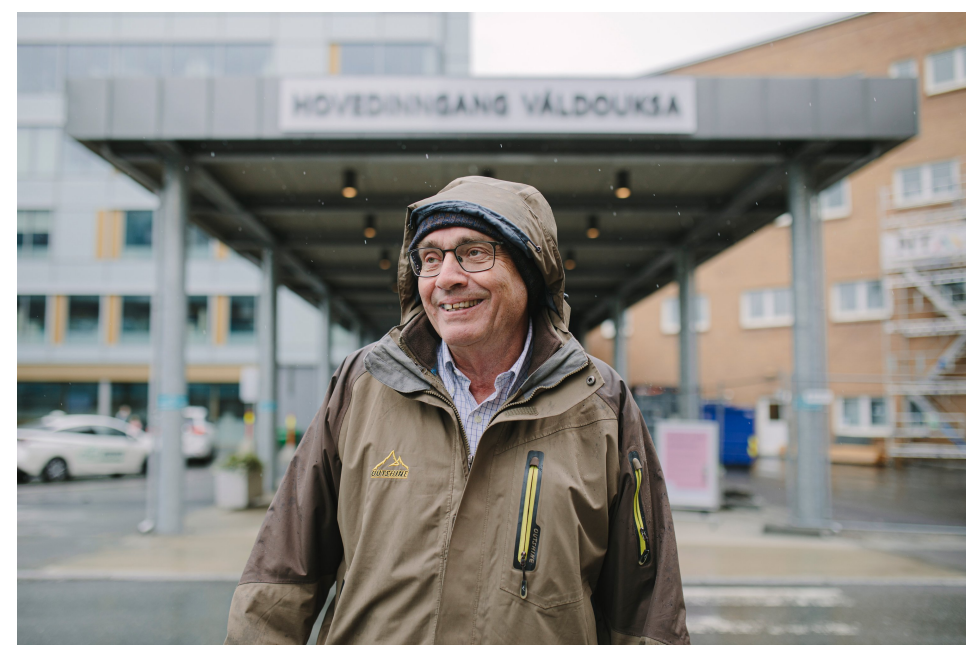

Foto: Marius Fiskum

- En fyr fra foreningen for norske studenter i utlandet fortalte at det gikk an å studere medisin i Spania. Da gikk jeg ut i bilen og sa til Astrid at jeg skulle gjøre nettopp det.

Høsten kom, og første stopp ble i Madrid. Men 40 graders varme og enorme kull var en litt for stor overgang. En spanjol på studenthjemmet skulle endre kursen på nytt:

- Vi kom i prat, og det viste seg at han var fra Santiago de Compostela. Han kunne fortelle at der var det kystklima og mye regn. Så dit bar det.

Et medisinstudium og et hav av inntrykk i det nordvestlige Spania senere kunne Arthur ta fatt på legelivet. Med seg hjem til Norge hadde han internasjonale bånd og ideer som formet valgene gjennom hele yrkeslivet. Dypest sitter verdien av å holde fast på kontakten med mennesket, selv om man bedriver vitenskap.

Vi må se hva pasientene trenger, og sørge for at de får det. Det er motivasjonen for å være doktor, i hvert fall for meg

- I Spania var koblingen mellom psyke og soma viktig, og jeg møtte helt andre holdninger enn det vi den gang hadde i Norge. Det tror jeg fortsatt på nå, 45 år senere. Det er noe allmenngyldig i det.

- Hvordan har det vært å ha de holdningene med seg inn i kirurgien?

- Som i andre fagfelt finnes det kirurger som er gode og dårlige på pasientkommunikasjon. Men det spesielle er å invadere medmennesker slik vi gjør i kirurgien. Og du skjønner fort at du er avhengig av teamet for å skape resultater. Jeg tenker det finnes flere likhetstrekk mellom kirurgien og psykiatrien i måten man snakker med og jobber med pasienten. Man er invaderende på forskjellig vis, og så tror jeg at psykiaterne har vært flinkere til å ivareta kontinuitet i pasient-lege-forholdet.

\section{Jakten på livsglede}

I Troms $\emptyset$ fant Arthur og Astrid mer enn bare arbeid. De kom hit for jobb og studier i 1978 og har ikke klart å rive seg vekk siden. Selv om det aktivt har vært oppe til diskusjon. Friluftsliv og naturopplevelser har blitt en sentral del av livet - i blomsterbed og hekk, så vel som på fjellet. For Arthur og familien er matauka en viktig del av tilværelsen. 
- Jeg synes det er veldig rett å høste av naturen på en ordentlig måte. I disse dager har vi sett hvor viktig det er. Da tenker jeg at storviltet i Norge er en proteinkilde som vi absolutt bør benytte oss ordentlig av.

Han har drevet rypejakt med hund i mange år, men den senere tiden har det meste av høstjakta gått til elgjakt. På fritidseiendommen ved Tromsø og i Reisadalen bedrives det fiske etter lyst, men noen sportsfisker ble Arthur aldri.

- Jeg er ikke noe glad i fang og slipp-prinsippet. Tenk hvis vi hadde drevet slik med elg? Det er det da ikke noe pent å gjøre? Å huke fast en fisk på krok, dra den inn til land, knipse et bilde og slippe den ut helt utslitt - og ikke ane hvor mange av dem som stryker med etterpå - er en «menneskenytegreie» jeg ikke skjønner meg på.

- I tillegg vet jeg at dersom jeg hadde kastet meg på fluebinding, ville jeg blitt litt vel innstendig.

\section{Bygg for fortiden}

Det ligger nysnø på fjellene rundt, selv om vi er i midnattssolens årstid under dette intervjuet. Vi går i durabelig tempo for å framkalle varme i nordnorsk sommer. Med en meters avstand raser vi over asfalten mellom universitets- og sykehusbygg.

Før var pasienthotellet en liten bortgjemt del av sykehusmassen ved Universitetssykehuset Nord-Norge. Nå er Pingvinhotellet med sine 240 rom det største pasienthotellet i NordEuropa. Derfra kan man se over mot det nye PET-senteret.

- Pasienthotellet gir en forsmak på framtidens pasientforløp. Og uten PET-senteret ville mye av den moderne diagnostikken måtte gjøres utenfor Nord-Norge, nikker Revhaug anerkjennende.

Han peker på den store nye A-blokka, tilholdssted for blant annet poliklinikker, kirurgi og intensivbehandling.

- Det er absolutt et fint bygg. Likevel, den måten vi bygger sykehus på er helt forkastelig. Vi vet hvor raskt den faglige utviklinga skjer, likevel bygges sykehus som kan stå i tusen år. Et argument er at det koster å måtte bygge på nytt om få år. Men et nytt bygg tilsvarer kun få år med drift.

- Det er drift som er dyrt?

- Ja. Prisen på byggene i seg selv er helt uvesentlig. Nå har vi nok en gang investert dyrt i et bunnsolid bygg på berget - et superbygg som om 20 år kommer til å være utdatert og må rives igjen. Klart enkelte deler av sykehusbygget må bygges varige, men eksempelvis operasjonsstuene bør bygges i ferdigstrukturer til lav kostnad.

- Byggmassen bør være mer fleksibel?

- Ja, mye mer fleksibel. Vi vet at alt endrer seg hurtig. Selv om det ser fint ut, bygger vi i dag for fortiden.

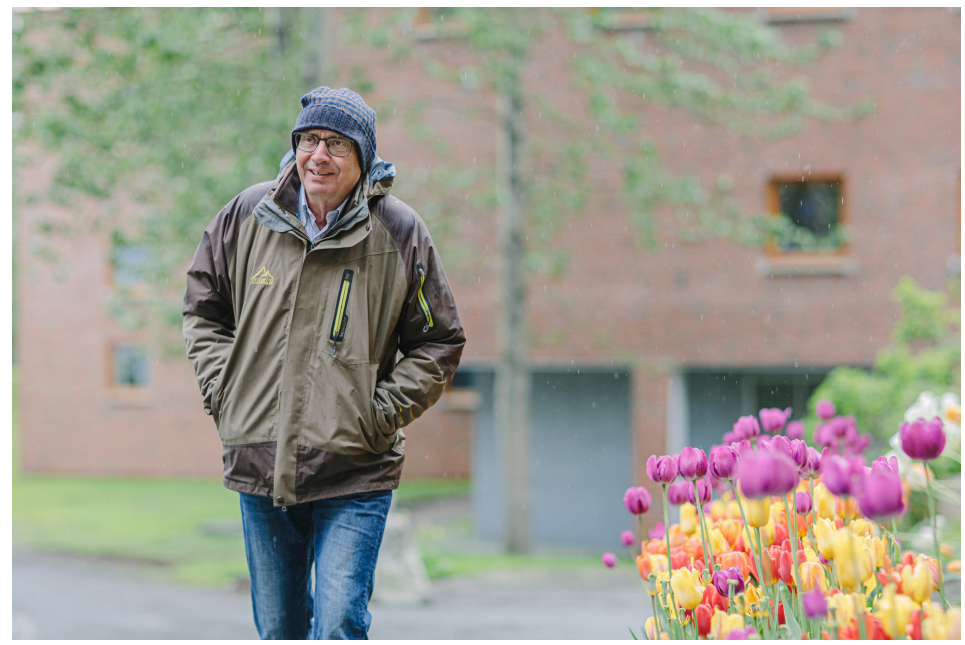




\section{Zoom ut}

Det sentrale for Arthur Revhaug er at pasientene i Nord-Norge har et godt tilbud. Det har motivert hans arbeid som kirurg, forsker og leder.

- Det er en balansegang å utfordre systemene våre på framtiden. Det tar tid å bygge opp gode fagmiljøer, men de kan ødelegges på et øyeblikk. For tiden som kommer, håper jeg det er tydeligere for alle at noe i helsevesenet må gjøres på en annen måte enn før. Det betyr at vi ikke kan satse alt på å kjøpe fra Kina eller leie inn folk utenfra. Vi må gi god nok betaling til folk som er her, og forlange at de blir flinke. Vi må alltid spørre oss om valgene vi gjør, er til pasientenes beste.

Det tar tid å bygge opp gode fagmiljøer, men de kan ødelegges på et øyeblikk

- Du er opptatt av å holde øyet på målet?

- Ja, man må ikke glemme målet. Det er så fort gjort å gå seg vill.

Når han til høsten skifter ham fra professor til professor emeritus ved Universitetet $\mathrm{i}$

Troms $\emptyset$ - Norges arktiske universitet, blir det på elektronisk vis. Selv en endringens mann kjenner at det byr mildt imot å tre ut av tjeneste over dataskjermen.

- Mine siste forelesninger holdes på Zoom. Det er på en måte veldig bra, men samtidig nesten så jeg får tårer i øynene. Interaksjonen med studentene er en kjempeviktig del av hele undervisningen. En utfordring i framtiden blir å finne ut hvordan vi best kan klare å kombinere dette. Mennesker må være sammen fysisk, de kan ikke bare være sammen på video.

Publisert: 26. oktober 2020. Tidsskr Nor Legeforen. DOI: 10.4045/tidsskr.20.o646

(C) Tidsskrift for Den norske legeforening 2020. Lastet ned fra tidsskriftet.no 